\title{
On farm test on supplementation effect of bypass fat on production performances of lactating crossbred cows
}

\author{
S.M. SONI, M.V. PATEL AND R.A. PATEL
}

\begin{abstract}
On farm trial was conducted on 20 lactating crossbred cows were randomly divided into two groups on the basis of milk yield (10 to $13 \mathrm{~kg} / \mathrm{day}$ ) and day of calving less than 60 days to see the effect of supplement bypass fat on milk yield and fat percentage for continuous three year (2012 to 2015). Cross bred cows were fed concentrate, green and dry fodder and wheat straw in control groups and addition of 100 grams of bypass fat was given in treatment group. Experimental feeding was continued up to 90 days. The average milk production and fat percentage was significantly higher in treatment group. Milk production efficiency was also significantly higher in bypass fat supplemented in comparison to control group. It was concluded that bypass fat supplementation@ $100 \mathrm{~g}$ per day per animal in cows significantly increase the milk production and fat percentage over the control group.
\end{abstract}

KEY WORDS : Bypass fat, Cow, Milk production, Fat percentage

How TO CITE THIS PAPER : Soni, S.M., Patel, M.V. and Patel, R.A. (2015). On farm test on supplementation effect of bypass fat on production performances of lactating crossbred cows. Res. J. Animal Hus. \& Dairy Sci., 6(2) : 149-152.

\section{MEMBERS OF RESEARCH FORUM}

Address for correspondence :

M.V. Patel, Krishi Vigyan Kendra, Ganpat Vidyanagar, MEHSANA (GUJARAT) INDIA

Associated Authors' :

S.M. Soni and R.A. Patel, Krishi Vigyan Kendra, Ganpat Vidyanagar, MEHSANA (GUJARAT) INDIA 